\title{
APPLICATION OF AIRBORNE HYPERSPECTRAL AND THERMAL IMAGES TO ANALYSE URBAN MICROCLIMATE
}

\author{
ANDRÁS JUNG ${ }^{1}$ - LÁSZLÓ TÖKEI ${ }^{1}$ - PÉTER KARDEVÁN ${ }^{2 *}$ \\ ${ }^{1}$ Corvinus University of Budapest, H-1118 Budapest, Villányi út 29-43. Hungary \\ (Phone: +36-1-482-6272 Fax: +36-1-482-6336) \\ ${ }^{2}$ Geological Institute of Hungary, H-1143 Budapest, Stefánia út 14. Hungary \\ (Phone: +36-1-251-0999 Fax: +36-1-251-0703)
}

e-mail:andras.jung@uni-corvinus.hu

(Received $28^{\text {th }}$ June 2006; accepted $2^{\text {nd }}$ June 2007)

\begin{abstract}
Urbanisation is a long standing problem and phenomenon all around the world. It means more and more challenges for scientists. Remote sensing techniques with high spectral and spatial resolution open novel approaches which enable the analysis of vegetated and non-vegetated urban surfaces with high heterogeneity. In this paper it is demonstrated how hyperspectral images and thermal maps can be used for detecting vegetated and built-in areas in a city. Methods were collected and developed that can describe different features of urban climate and ecological state. The most important vegetation indices and urban climate parameters were calculated: red-edge position values for green places, different NDVIs, defining the role of vegetation in surface temperature carried out by masking method, urban heat island intensity, horizontal surface temperature gradient by means of Fourier-transformation and classified thermal maps.
\end{abstract}

Keywords: urban climate, hyperspectral remote sensing, thermal images, red-edge, urban vegetation

\section{Introduction}

The UNO [20] Report 2005 projects that $50 \%$ of the world's population, and $75 \%$ of Europe's will be living in cities by 2010. The social, environmental and economic problems caused by urbanisation will present more and more challenges for scientists.

Recent advances in remote sensing have allowed applied disciplines to bring aerial and satellite imaging to provide a helpful tool in scientific problems. There are very different materials with very different energy budgets within only a few square meters in a city.

Our main research aim was to analyse a remote-sensing database with high spectral and spatial resolution, using both published methodologies and techniques developed by us, in order to be able to help experts who are dealing with cities or urban air quality projects [13], [16], [22].

Our database gave us two directions of investigation, using both short and long wavelengths that contained at least 10 bands in the spectral region of $600-800 \mathrm{~nm}$ to investigate the urban environment. We therefore needed to construct a vegetation index that can consider 10 or more bands. We further needed to consider thermal bands to study differences in surface temperature within the city [1], [9], [10]. Beyond these general aims our specific goals were to determine indices that could characterize built-up urban areas on the basis of a hyperspectral data cube and thermal sensor data as follows:

- Determine urban heat-island intensity; 
- Determine the horizontal urban surface temperature gradient and the "oasiseffect" of urban green spaces;

- Determine the contribution of the whole vegetated area to the temperature distribution of a city surface;

- Establish remote sensing methods (red-edge method) that can suitably characterize vegetation with a positive effect on the urban environment, and set up the statistical tests needed to confirm the relationship.

There are well-known methods to define red-edge position [2],[3];[5],[8],[15]. In our work we have carried out numerical derivation (calculating with the second derivative) on the reflectance curve at the red and infrared end of the spectrum, where the red-edge position would be determined. We did not prefer to use the linear method because of the 10 spectral sampling points [12]. Results were compared with other vegetation indices (NDVI) and surface temperature values. Questions were formed as follows:

- Is there a statistically significant relationship between red-edge position and traditional vegetation indices?

- Is there a statistically significant relationship between vegetation surfacetemperature differences and traditional vegetation indices?

- Is there a statistically significant relationship between vegetation surfacetemperature differences and red-edge position?

\section{Materials and Methods}

\section{Study area}

The first Hungarian aerial hyperspectral imaging programme took place within the framework of the 2002 HYSENS project. The images were taken on the afternoon of the 18th of August 2002. The images included complete coverage of the town of Gyöngyös (GPS coordinates: N 4748.9', E 1958.7'). This provided a suitable basis for our investigations. As the images were taken on a summer day, the longwave radiative properties of the urban surface could be observed with good results (soil temperature at a depth of $2 \mathrm{~cm}: 07: 00 \mathrm{~h}-19 \mathrm{oC} ; 13: 00 \mathrm{~h}-31.4 \mathrm{oC} ; 19: 00 \mathrm{~h}-24.2 \mathrm{oC}$, measurements taken at the Károly Róbert College meteorologic station).

\section{Data collection and analysis}

The effectiveness of urban climate research by remote sensing depends on the properties of the camera equipment. Our images were taken using a DAIS 7915 airborne imaging spectrometer equipped with an additional thermal sensor. Its spatial resolution was $5 \mathrm{~m}$. Our data base also contained topographic maps, true-colour airborne images and field surveys.

With the collaboration of the Geological Institute of Hungary (MÁFI) we were able to obtain true-colour airborne images (spatial resolution of $0,65 \mathrm{~m}$ ) produced by Légiproject 2000 (taken in July that year) from the Institute of Geodesy, Cartography and Remote Sensing (FÖMI). We had access to EOTR topographic maps covering Gyöngyös in 1:10000 scale in two cuts (76-244 and 76-422) [11];[21]. 
Table 1. Most important built-in methods used during the investigation.

\begin{tabular}{|c|c|c|c|}
\hline $\begin{array}{l}\text { Origin } \\
\text { of the } \\
\text { method }\end{array}$ & $\begin{array}{l}\text { Name } \\
\text { of the } \\
\text { method } \\
\text { applied }\end{array}$ & $\begin{array}{c}\text { Database } \\
\text { requirements }\end{array}$ & $\begin{array}{c}\text { Explanation } \\
\text { of application }\end{array}$ \\
\hline \multirow{4}{*}{ 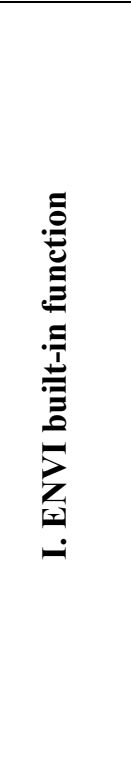 } & Masking & $\begin{array}{l}\text { After supervised } \\
\text { classification of } \\
\text { resampled NDVI } \\
\text { images, merging the } \\
\text { classes into two } \\
\text { groups with values } 0 \\
\text { and } 1\end{array}$ & $\begin{array}{c}\text { To separate vegetated and } \\
\text { non-vegetated areas }\end{array}$ \\
\hline & $\begin{array}{c}\text { MNF } \\
\text { transformati } \\
\text { on } \\
\end{array}$ & Hyperspectral image & $\begin{array}{c}\text { To reduce noise- } \\
\text { component of } \\
\text { hyperspectral data cube }\end{array}$ \\
\hline & $\begin{array}{c}\text { Fourier } \\
\text { transformati } \\
\text { on }\end{array}$ & $\begin{array}{l}\text { Original thermal } \\
\text { image }\end{array}$ & $\begin{array}{c}\text { To decrease spatial } \\
\text { variability of the original } \\
\text { thermal image because of } \\
\text { gradient calculation }\end{array}$ \\
\hline & $\begin{array}{l}\text { Image } \\
\text { fusion }\end{array}$ & $\begin{array}{c}\text { Airborne true-colour } \\
\text { and hyperspectral } \\
\text { image }\end{array}$ & $\begin{array}{l}\text { To merge the benefits of } \\
\text { an image with good } \\
\text { spatial resolution and } \\
\text { another image with good } \\
\text { spectral resolution }\end{array}$ \\
\hline
\end{tabular}

Table 1 and 2 list the methods used and implemented in our work [7],[17],[18]. We have grouped procedures according to whether they were built in into the ENVI software or whether they had to be worked out to suit our aims. Descriptions and explanations are provided in column 4.

Methods with tangential bearing on our work, such as mosaic composition to join separate topographic cuts into one, are not included. Supervised classification was also applied as preparation for image masking. In Table 2 we have listed several vegetation indices that were defined in our work, each of which brought us closer to comparing the benefits of the red-edge method with various traditional vegetation indices. For our calculations we used the built-in functions of ENVI 3.6, or wrote programs in IDL where it was necessary (for instance calculating of red-edge position). 
Table 2. Most important developed methods used during the investigation

\begin{tabular}{|c|c|c|c|}
\hline $\begin{array}{l}\text { Origin } \\
\text { of the } \\
\text { method }\end{array}$ & $\begin{array}{c}\text { Name } \\
\text { of the } \\
\text { method } \\
\text { applied }\end{array}$ & $\begin{array}{l}\text { Database } \\
\text { requirements }\end{array}$ & $\begin{array}{l}\text { Explanation } \\
\text { of application }\end{array}$ \\
\hline \multirow{6}{*}{ 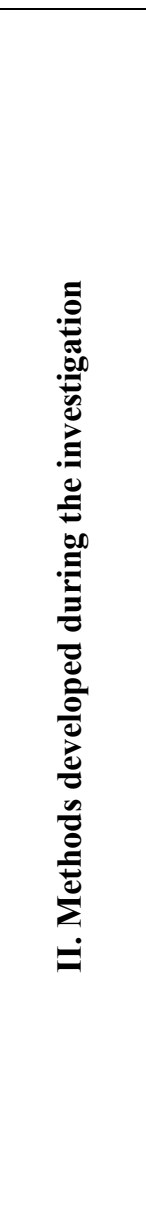 } & $\begin{array}{l}\text { Vegetation index } \\
\text { based on curve } \\
\text { analysis: } \\
\text { determination of red- } \\
\text { edge position }\end{array}$ & \begin{tabular}{l}
\multicolumn{1}{|c|}{ Hyperspectral } \\
image in spectral \\
region $600-800 \mathrm{~nm}$ \\
(with 10 bands) \\
reduced by MNF \\
transformation
\end{tabular} & $\begin{array}{l}\text { To work out a } \\
\text { vegetation index for } \\
\text { hyperspectral images } \\
\text { to replace traditional, } \\
\text { multispectral NDVI }\end{array}$ \\
\hline & $\begin{array}{l}\text { Traditional } \\
\text { vegetation indices: } \\
\text { NDVI, SAVI, } \\
\text { NDVI(11/16), } \\
\text { SAVI(11/16) }\end{array}$ & $\begin{array}{l}\text { Hyperspectral } \\
\text { image in spectral } \\
\text { region } 600-800 \mathrm{~nm} \text {, } \\
\text { reduced by MNF } \\
\text { transformation }\end{array}$ & $\begin{array}{l}\text { For comparison of } \\
\text { new and traditional } \\
\text { vegetation indices }\end{array}$ \\
\hline & $\begin{array}{l}\text { Horizontal } \\
\text { temperature gradient }\end{array}$ & $\begin{array}{l}\text { Thermal image } \\
\text { filtered by Fourier } \\
\text { transformation }\end{array}$ & $\begin{array}{l}\text { To calculate } 1 \mathrm{~m} \text { surface } \\
\text { temperature rate in the } \\
\text { vegetation, at the border } \\
\text { between vegetation and } \\
\text { built-up area and on built- } \\
\text { up areas }\end{array}$ \\
\hline & $\begin{array}{l}\text { "Heat-island" } \\
\text { phenomenon }\end{array}$ & $\begin{array}{l}\text { Original thermal } \\
\text { image }\end{array}$ & $\begin{array}{l}\text { To determine the } \\
\text { temperature difference } \\
\text { between the centre and the } \\
\text { suburban area }\end{array}$ \\
\hline & $\begin{array}{l}\text { "Oasis" } \\
\text { phenomenon }\end{array}$ & $\begin{array}{l}\text { Thermal image } \\
\text { filtered by Fourier- } \\
\text { transformation }\end{array}$ & $\begin{array}{l}\text { To determine how } \\
\text { vegetation can moderate the } \\
\text { temperature extremes on } \\
\text { built-up areas }\end{array}$ \\
\hline & $\begin{array}{l}\text { Role of vegetation } \\
\text { in surface } \\
\text { temperature }\end{array}$ & $\begin{array}{l}\text { Original thermal } \\
\text { image, but masked }\end{array}$ & $\begin{array}{l}\text { To determine how the } \\
\text { distribution of surface } \\
\text { temperature changes } \\
\text { depending on plant } \\
\text { coverage }\end{array}$ \\
\hline
\end{tabular}

The methods we have developed and the results obtained relate to data from a single date, because airborne images were taken on one summer day. We could investigate the spatial features of an urban environment and not its temporary changes. It is important to emphasize that the dynamic properties of cities are important as well and our methods - with some changes - could also be applied for urban change detection.

\section{Results}

\section{Distribution of vegetation surface temperature}

On the basis of field observations and true-colour airborne images, it was established that areas with large biomass like trees (height: 15-20, diameter: 10-15 m), other wooded districts with good water conditions (brook-sides) or cultivated areas with large biomass (orchards) were found to be on areas with a temperature interval of 17-19 oC in the thermal image. Areas with a temperature interval of 19-21 oC were characteristic for one-layered vegetation like football pitches, grassy parks, meadows or other grass- 
covered areas. Surfaces with temperatures of $21-23$ oC are transition zones that are next to the vegetation but close to bare soil or built-up areas.

\section{Intensity of surface heat island}

On the basis of our calculations the built-up areas had an average surface temperature of $26 \mathrm{oC}$, the garden-city had $23 \mathrm{oC}$, and the suburb had $21 \mathrm{oC}$. From those values the heat island intensity in Gyöngyös on the 18th August 2002 was found to be 5 oC.

\section{Horizontal temperature gradient and 'oasis-effect'}

In cities it is easy to observe the "oasis-effect". Especially on hot summer days, green areas have a very valuable microclimatic effect on the artificial surfaces (concrete, asphalt) nearby. The value of the horizontal temperature gradient was an order of magnitude greater on built-up urban surfaces than on vegetated or transitional zones. For the whole analysed territory the mean surface temperature gradient was $0.015 \mathrm{oC} \cdot \mathrm{m}-1$.

The horizontal surface temperature gradient can be used to determine the cooling effect of vegetation as opposed to the urban effect on vegetation. We found a $0.7 \mathrm{oC}$ temperature difference between vegetated and transitional zones, and a $3.1 \mathrm{oC}$ temperature difference between vegetated and built-up areas. It was concluded that the gradient over the sample range (0-120 m, 121-240 m, 241-360 m) declined with increasing proximity to vegetated surface. The "oasis-effect" lowers the surface temperature values around a vegetated surface, especially on hot summer days, and the temperature distribution will be more balanced.

\section{Temperature of urban surfaces with and without vegetation}

It was observed (as illustrated on Fig. 1) that when an urban area was covered with vegetation and with other artificial surfaces too then $50 \%$ of these areas were in the 19 23 oC temperature interval, but when vegetation was masked this fell to $34.3 \%$ of the classified pixels.

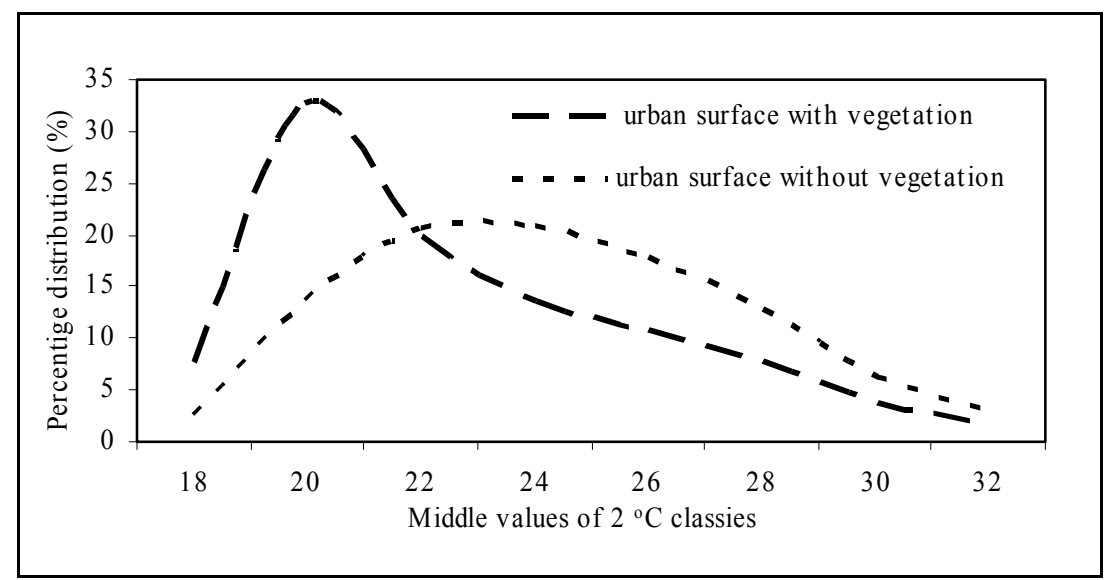

Figure 1. Role of vegetation in urban surface temperature distribution.

Before masking, $7.5 \%$ of the pixels were in the $17-19$ oC interval; after masking only $2.4 \% .32 .8 \%$ of pixels fell into the $19-21$ oC interval; masking reduced this to 
$13.6 \%$. So it can be concluded that without vegetation the temperature of urban surfaces will be higher, and masking effectively demonstrates the role of vegetated areas in cities.

\section{The statistical relationship between red-edge position and NDVI}

NDVI was calculated from the red and near-infrared spectral range $(600-700 \mathrm{~nm})$. The relationship between NDVI values and red-edge position (hereafter: REP) was analysed (as illustrated by Fig. 2). It was determined that an exponential curve provides the best fit to the data. The equation given in formula (Eq. 1), the independent variables of which were in a bounded interval of $0.56 \leq \mathrm{NDVI} \leq 0.96$, and dependent variables in a bounded interval of $714 \mathrm{~nm} \leq \mathrm{REP} \leq 726 \mathrm{~nm}$. The equation shows that the rate of change in the NDVI index eventually outpaces that of the REP index. The indices differ to a greater extent at higher values.

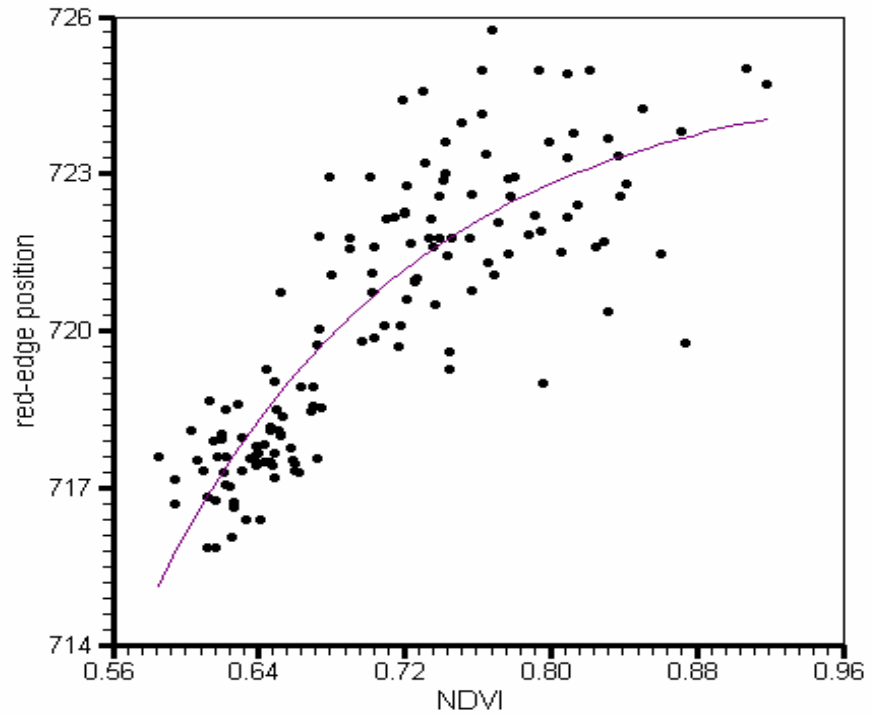

Figure 2. The fitted curve for the relation of NDVI and REP.

The higher are the values of NDVI and REP, the higher is the observed variation. With NDVI values below 0.72 a linear relationship between independent and dependent variables is obtained. This relates to an area covered with one-layer vegetation such as grassy meadow, football field (NDVI < 0.76). In this case the two indices have very similar features.

$$
R E P=A+B \cdot \operatorname{EXP}(-C \cdot N D V I), \quad(\mathrm{nm})
$$

where $R E P=$ red-edge position, $A=725.008, B=-593.062, C=6.999$,

$N D V I=$ NDVI calculated over a broad interval.

We concluded that REP provides a better indicator for changes in vegetation properties where there are more than two spectral bands in the reflectance spectrum in the red and near infrared region. An exponential relationship [6] was also observed with 
other vegetation indices (NDVI(11/16), SAVI, SAVI(11/16)). (11/16) referring to bands 11 and 16 of DAIS 7915.

\section{The statistical relation between NDVI(11/16) and the surface temperature of vegetation}

During the investigation it was established that NDVI (11/16) values increase in inverse proportion to the surface temperature of vegetated areas (as illustrated on Fig. $3)$. To interpret and explain temperature changes on the surface, a variable $\Delta$ Ts was introduced. This expresses the temperature difference of a given vegetated surface as compared with a reference area. In water management, it is good practice to take a cultivated grassy field as a reference. For this study a football pitch was chosen. When more transpirative and photosynthetically active layers are above each other within a canopy then the energy absorbed by plants can moderate the surface temperature of the canopy due to transpiration. While the whole canopy is involved in this process, the result can only be observed on the surface because the remote sensor measures only the surface temperature.

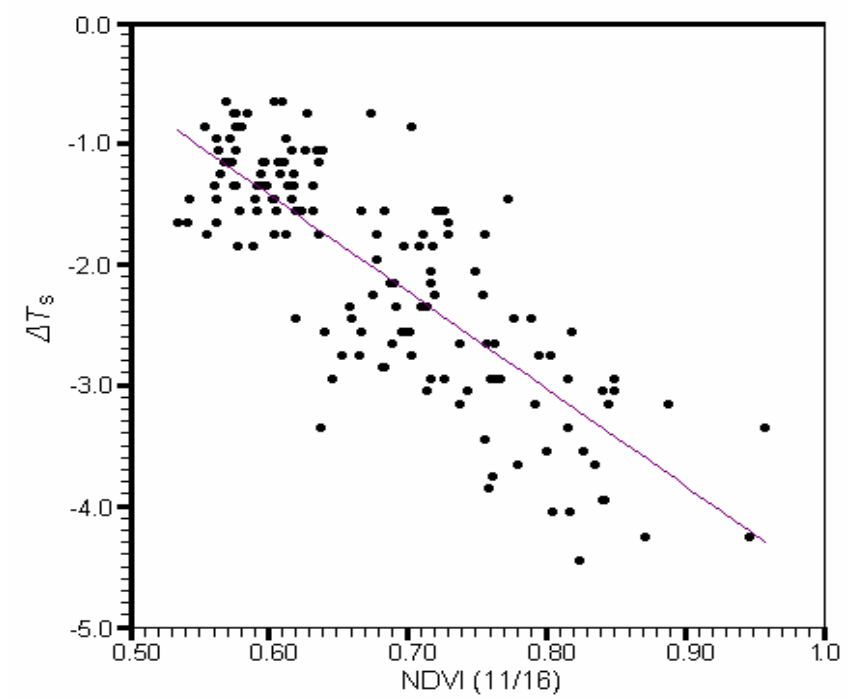

Figure 3. The fitted curve for the relation of $N D V I(11 / 16)$ and $\Delta T_{s}$.

According to the statistical results the NDVI(11/16) values determine on (R) $81 \%$ the values of surface temperature of vegetation with a confidence level of $95 \%$. The best fitting curve was a linear function. The equation given in formula (2) has independent variables in a bounded interval of $0.5 \leq \mathrm{NDVI}(11 / 16) \leq 1.0$, and dependent variables in a bounded interval of $-5.0 \leq \Delta \mathrm{Ts} \leq 0.0 \mathrm{~K}$. Values of NDVI(11/16) are valid for the time of investigation and for a given phenological state.

$$
\Delta T_{\mathrm{s}}=A \cdot \operatorname{NDVI}(11 / 16)+B,
$$

where $\Delta T_{\mathrm{s}}=$ temperature changes compared to reference, $A=-8.036, B=3.400$, NDVI $(11 / 16)=$ NDVI calculated from bands 11 and 16 of the DAIS 7915 . 


\section{The statistical relationship between REP and the surface temperature of vegetation}

We have investigated the relationship of REP to $\triangle T$ s. The surface temperature of the canopy is influenced by transpiration on all the leaf cover, while vegetation indices are determined by the water and chlorophyll content detected in the canopy surface at a macroscopic (canopy geometry) and microscopic (cellular) level. It is important to remember that only the surface and its physiological features can be observed by remote sensors.

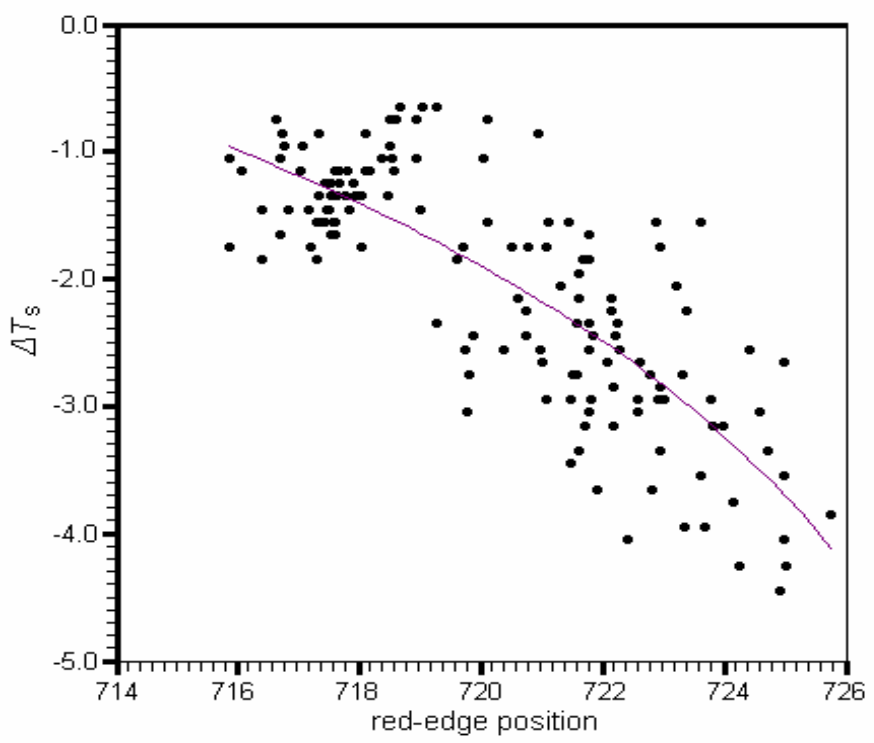

Figure 4. The fitted curve for relation of REP and $\Delta T_{s}$.

According to our results, one- and multi-layer canopies can be distinguished on the basis of REP values. REP values of less than $720 \mathrm{~nm}$ are characteristic of homogenous, one-layered vegetation (grassy fields) and REP values greater than $720 \mathrm{~nm}$ are typical for multi-layered wooded canopies (height: 15-20 m, diameter: 10-15 m) on the area investigated. One of our most important results was the exploration of the relationship between REP and canopy surface temperature changes (as illustrated on Fig. 4). The comparison can be qualified by the kappa-index and error matrix widely used in remote sensing. The question was whether the spatial clusters of the REP values can be successfully fitted to spatial clusters of surface temperature changes.

It must be mentioned that grassy and homogenous, one-layer vegetation (height $<$ $10-15 \mathrm{~cm}$ ) can be separated with high probability from tree-canopies (height 15-20 m, diameter: $10-15 \mathrm{~m}$ ) on the basis of REP and $\Delta$ Ts maps. With these two classes we have calculated the error matrix and kappa index. The reference was the $\Delta$ Ts map, as such a detailed and spatially accurate thermal map can be established by remote sensors only. The overall accuracy was found to be $91.24 \%$ and the kappa index was 0.81 . We found these values encouraging. The implication is that an REP map can be used to deduce surface temperature changes at the same pixel with a probability of $91 \%$. The curve of best fit for the relationship between REP and $\triangle T$ s is a logarithmic function.

The equation given in formula (3) has independent variables in a bounded interval of $714 \leq \mathrm{REP} \leq 726 \mathrm{~nm}$, and dependent variables in a bounded interval of $-5.0 \leq \Delta \mathrm{Ts} \leq 0.0$ $\mathrm{K}$. The correlation coefficient (R2) was 0.65 . 


$$
\Delta T_{\mathrm{s}}=A+B \cdot \ln ((C-R E P) / D),
$$

where $\Delta T_{s}=$ temperature changes compared to reference,

$A=-2.559, \mathrm{~B}=2.861, \mathrm{C}=730.706, \mathrm{D}=8.500$, $R E P=$ red-edge position.

With higher REP values (REP $>720 \mathrm{~nm})$ the surface temperature changes $(\Delta \mathrm{Ts})$ were larger than changes in REP values since the whole surface of a tree canopy is always larger than the outward surface of the same canopy as compared to grassy fields. The cooling effect is correspondingly greater for trees than for grassy land.

\section{Discussion}

Experts dealing with urban and landscape planning should make use of new remotesensing and environmental monitoring technologies to make better, faster and more effective decisions. End-users need easy-to-use graphical solutions. We conclude that REP provides a better index than NDVI, when we have more than two spectral bands in the red and near-infrared fragment. Developments in remote sensing will allow us to introduce new methods for analysing urban vegetation.

It can be assumed that REP is a better indicator than NDVI if there are more than two bands to analyse. We have two recommendations that can help experts dealing with canopy climate or biophysics.

- If a thermal map covering a vegetated area is available, but its spatial resolution is insufficient, then the spatial resolution can be enhanced using a high-resolution vegetation index map derived from the red and near-infrared spectrum. The thermal image may be sharpened using image fusion.

- As discussed above, if thermal image data is not available, temperature changes can be estimated by calculating REP values for the area in question. Several ecological and biophysical models take the surface temperature of the canopy into consideration, yet detailed thermal information is not always available. This problem can be alleviated by this method.

Remote sensing and GIS form part of an involved decision-making process [4];[14],[19]. Of course, whether stakeholders and decision-makers want to benefit from their use is another question. On the basis of our results, we would like to deliver spatial decision-making systems that can be deployed in urban climate planning and urban green-space design to optimise human comfort, and resolve special and general problems of urban ecology and urban green area systems.

\section{REFERENCES}

[1] Bartholy, J., Pongrácz, R., Dezső, Zs., Mészáros, R., Kern, A., Barcza, Z. (2002): Local scale climatological characteristics of urban built-up areas for the Carpathian Basin. Abstracts of the International Conference on Climate Change and Built Environment. UMIST, Manchester. 8-9 April. 137.

[2] Broge, N. H., Lablance, E. (2000): Comparing prediction power and stability of broadband and hyperspectral vegetation indices for estimation of green leaf area index and canopy chlorophyll density. - Remote Sensing of Environment, 76: 156-172. 
[3] Broge, N. H., Mortensen, J. V. (2002): Deriving green crop area index and canopy chlorophyll density of winter wheat from spectral reflectance data. - Remote Sensing of Environment, 80: 45-57.

[4] Burai, P., Tamás, J. (2004): Hyper- and multispectral remote sensing technologies in precisional agricultural water management. - Proc. III. Alps-Adria Scientific Workshop, Dubrovnik, Croatia, 54-57.

[5] Demetriades-Shah, T.H., Steven, M.D., Clark, J.A. (1990): High resolution derivative spectra in remote sensing. - Remote Sensing of Environment, 33:, 55-64.

[6] Gilabert, M.A., Gandía, S., Meliá, J. (1996): Analysis of Spectral-Biophysical Relationships for Corn Canopy. - Remote Sensing of Environment, 55: 11-22.

[7] Greiwe, A., Bochow, M., Ehlers, M. (2005): Segmentbasierte Fusion geometrisch hoch aufgelöster und hyperpsektraler Daten zur Verbesserung der Klassifikationsgüte am Beispiel einer urbanen Szene. - Photogrammetrie-Fernerkundung-Geoinformation, 6: 485-494.

[8] Guyot, G., Baret, F., Major, D.,J. (1988): High spectral resolution: determination of shifts between the red edge and near infrared. - International Archives of Photogrammetry and Remote Sensing, 27 (11), 750-760.

[9] Jung, A., Kardeván, P., Tökei, L. (2004): Detection of urban effect on vegetation in a less build-up hungarian city by hyperspectral remote sensing. - Physics and Chemistry of the Earth, 30: 255-259.

[10] Jung, A., Tőkei, L., Kardeván, P., Nagy, Zs., (): Investigating of Plant Reflectance Spectrum between $623 \mathrm{~nm}$ and $780 \mathrm{~nm}$ with Hyperspectral Airborne Imaging Technology. - Erdei Ferenc III. Tudományos Konferencia. 2005. 08. 23-24., Band II. 880-884.

[11] Kardeván, P., Vekerdy, L., Róth, L., Sommer, S., Kemper, T., Jordán, Gy.,Tamás, J., Pechman, I., Kovács, E., Hargitai, H., László, F. (2003): Outline of scientific aims and data processing status of the first Hungarian hyperspectral data acquisition flight campaign, HYSENS 2002 HUNGARY. - Proc. at the 3rd EARSEL Workshop on Imaging Spectroscopy, Herrsching, Germany, May 13-16 2003: 324-332.

[12] Kumar, L., Schmidt, K., Dury, S., Skidmore, A. (2001): Imaging Specrometry and Vegetation Science. In: Van der Meer, F. D., De Jong, S.M. (Ed.), Imaging Spectrometry (pp. 115-143). - Dordrecht Kluwer Academic Publishers.

[13] Landsberg, H. E. (1979): Atmospheric changes in a growing community (the Columbia, Maryland experience). - Urban Ecology, 4 (1): 53-81.

[14] Láng, Z., Kriston-Vizi J., Molnár S. (2000): Reseaerching of applicability of precision farming in fruit production (in Hungarian). - MTA, AMB Kutatási és fejlesztési tanácskozás, Gödöllő.

[15] Mutanga, O., Skidmore, A.K. (2004): Integrating imaging spectroscopy and neural networks to map grass quality in the Kruger National Park, South Park. - Remote Sensing of Environment, 90: 104-115.

[16] Oke, T.R., Maxwell, G.B. (1967): Urban heat island dynamics in Montreal and Vancouver. - Atmospheric Environment, 9 (2): 191-200.

[17] Segl, K., Roessner, S., Heiden, U., Kaufmann, H. (2003): Fusion of spectral and shape features for identification of urban surface cover types using reflective and thermal hyperspectral data. - ISPRS Journal of Photogrammetry \& Remote Sensing, 58: 99-112.

[18] Stümer, W., Köhl, M. (2005): Kombination von terrestrischen Aufnahmen und Fernerkundungsdaten mit Hilfe der k-naechste-Nachbarn-Methode zur Klassifizierung und Kartierung von Waeldern. - Photogrammetrie-Fernerkundung-Geoinformation, 1: 23-36.

[19] Tamás, J., Takács, P., Juhács, Cs. (2004): Integrated Field Scale Water Management Technology. - Proc. III. Alps-Adria Scientific Workshop, Dubrovnik, Croatia, 112-117.

[20] UNO Report, World Urbanization Prospects (2005): The Population Database. http://esa.un.org/unup/. 
[21] Vekerdy, Z., Kardeván, P., Róth, L., Jordán, Gy., László, F., (): Hyperspectral PilotProject in Hungary (in Hungarian) - GEO 2002 Magyar Földtudományi Szakemberek VI. Világtalálkozója. Sopron 2002. augusztus 21-25. Kelet és Nyugat Határán, P10.

[22] Voogt, J.A., Oke, T.R. (2003): Thermal remote sensing of urban climate. - Remote Sensing of Environment, 86: 370-384. 